\title{
Effect of Different Cooking Methods on the Nutritional Composition of Tilapia (Oreochromis Sp.)
}

\author{
Fabiola Hernández-Sánchez ${ }^{\mathrm{a}}$, Martha Elena Aguilera-Morales ${ }^{\mathrm{b}}$, M.Sc. José Luis Lorenzo- \\ Manzanarez $^{\mathrm{a}}$, Leticia Guadalupe Navarro-Moreno ${ }^{\mathrm{a}}$, Tan Yie-Hua ${ }^{\mathrm{c}}$, and Cirilo Nolasco- \\ Hipolito $^{\text {a* }}$ \\ ${ }^{a}$ Institute of Biotechnology, Universidad del Papaloapan Campus Tuxtepec, Circuito Central \\ $N^{o}$ 200, Col. Parque Industrial, C.P. 68301, Tuxtepec, Oaxaca, México \\ ${ }^{b}$ Institute of Agricultural Engineering, Universidad del Papaloapan, Campus Loma Bonita. \\ Av. Ferrocarril No 1, Col. Ciudad Universitaria, C.P. 68400, Loma Bonita, Oaxaca, México \\ ${ }^{c}$ Department of Chemical Engineering, Curtin University, Malaysia, CDT 250, Miri 98009, \\ Sarawak, Malaysia
}

\begin{abstract}
Tilapia (Oreochromis sp.) is a fish that is gaining ground in cultivation and sales because of its nutritional properties: high protein content, vitamins, and minerals with few unhealthy saturated fats as in red meats. In this work the cooking effects on the proximate analysis, water activity $\left(a_{w}\right)$, and $p H$, in addition to the electrophoretic, and fatty acid profile in Tilapia using an electric oven, microwave and steaming as cooking methods were evaluated. The results showed that the nutritional components of Tilapia changed significantly $(p<0.05)$ at two temperatures and two potencies used. Microwave and steaming preserved better the proteins in the Tilapia after its cooking. Intensity and number of bands of proteins after electrophoresis were depending on the type of treatment used. On the other hand, the electric oven method at 2 temperatures $\left(60^{\circ} \mathrm{C}\right.$ and $\left.80^{\circ} \mathrm{C}\right)$ resulted with the highest increase in essential fatty acids $(45 \% \mathrm{w} / \mathrm{w}$ and $36 \% \mathrm{w} / \mathrm{w})$, with a slight decrease in the $\omega-6$ family, because of probable hydrolysis or oxidation of the same. The steam cooking showed a slight increase in essential fatty acids (from $43.72 \%$ to $44.92 / 48.24$ ) at $60{ }^{\circ} \mathrm{C}$ and $80{ }^{\circ} \mathrm{C}$ respectively, but microwave oven preserved better the proteins, indicating that this could be a good method for cooking Tilapia.
\end{abstract}

Keywords: Tilapia, Oreochromis sp., Cooking effect, Nutritional components, Unsaturated fatty acids.

\section{Introduction}

Both freshwater and saltwater fish provide a range of vitamins and minerals, are low in saturated fatty acids (FA) and are an excellent source of protein and essential $\omega-3$ FA. Long-chain $\omega-3$ FA derived from fish oils, mainly docosahexaenoic acid (DHA, 22:6 $\omega-3$ ) and eicosapentaenoic acid (EPA, 20:5 $\omega-3)$, can reduce the risk of chronic illnesses, such as cardiovascular diseases, diabetes, inflammatory diseases and neurological disorders [1]. Freshwater fish contain less fat than any other source of animal protein and are low in the $\omega-6$ fatty acids, which can be commonly found in red meat. Healthy diet guidelines recommend that eating no less than $150 \mathrm{~g}$ of cooked fish per week can reduce the risk of a range of diseases [2]. Tilapia (Oreochromis sp.) is a freshwater fish species in high demand worldwide.

* Corresponding author. Tel.: +52-281-872 9230; fax: +52-281-872 9230

E-mail address: cnolasco36@gmail.com.

Manuscript History:

Received 11 March, 2020, Revised 24 April, 2020, Accepted 29 April, 2020, Published 30 April, 2020

e-ISSN: 2289-7771 
Its popularity has progressively grown since it entered the top ten list of the most frequently consumed seafood products in the U.S. in 2002.

To be commercially acceptable, food must be sterile but not overcooked. However, irrespective of the applied technique, sterilisation negatively impacts the products' qualities, by inducing flavour, changes, texture modification, colour variation, decrease in nutritional values and damages to the sensory quality [3-5]. Moreover, preparation methods of cooking foods, and the cooking conditions, such as heating temperature, process time, modify the properties of the meat significantly.

The desirable aroma during the meat cooking is mainly due to the releasing of non-volatile compounds derived from free amino acids, reducing sugars, peptides, nucleotides, vitamins and unsaturated fatty acids (UFA) and the interaction of these compounds [6]. Moreover, the heating process can lead to oxidation of lipids, being the key factor to deteriorate the meat, resulting in unpleasant taste and odours, rancidity, changes of components, loss of essential FA and production of toxic compounds [7-8]. The accumulation of lipid peroxidation products in human tissues is a major cause of inflammatory diseases, such as atherosclerosis and cancer [8]. Lipid oxidation can be controlled and reduced through various thermal operating conditions (temperature and cooking time).

The most common methods for cooking fish are frying, baking and steaming. Few literature studies have quantified the effects of different cooking methods on the nutritional properties of Tilapia [9-13]. Moreover, the main focus has been on the heat impact on the protein and lipid contents because biochemical constituents are exceptionally heat-sensitive [14-17].

Electrical heating devices, for example, a microwave oven, convert the electrical energy to nonionising electromagnetic radiation. The heatwaves are generated via the direct contact between the electromagnetic waves and the foods. These instruments have been implemented for cooking foods through different cooking methods, such as baking, thawing, drying, pasteurising and sterilizing [18]. A dielectric heating system (electrical heating instrument) shortens the cooking time, and so it can minimise the damage to the physicochemical and nutritional properties of the food [19].

This work aimed to investigate the effect of three cooking processes (steaming, electric oven and microwave oven cooking) of Tilapia (Oreochromis niloticus) fillet on the water activity $\left(\mathrm{a}_{\mathrm{w}}\right)$, electrophoretic protein profile and nutritional content, especially, the protein, total lipids, ash, moisture and fatty acids. The results from this research will provide the nutritional properties of the cooked Tilapia species to the consumers and benefit the commercial sector in the industrialisation and further production of value-added Tilapia meat.

\section{Materials and methods}

\subsection{Sampling preparation}

Tilapias (Oreochromis sp.) from Cerro de Oro Dam $\left(18^{\circ} 0^{\prime} 2.88^{\prime \prime} \mathrm{N}, 96^{\circ} 15^{\prime} 50.04 \mathrm{~W}\right)$, and weighing 0.7 to $0.8 \mathrm{~kg}$ were purchased at the local Market of Tuxtepec City, Oaxaca, Mexico. Samples were further processed in the Food Science Workshop of the Universidad del Papaloapan (Tuxtepec, Mexico). The fish samples were cut into fillets $(2.0 \times 2.5 \times 0.5 \mathrm{~cm})$. Random samples were chosen to cook by three different methods (steaming, electric oven and microwave).

\subsection{Cooking methods}

\subsubsection{Steaming:}

An electric grill (WiseStir® model MSH-20, Witeg Labortechnik GmbH, Germany) with controllable temperature was used to generate steam inside an aluminium container filled with water. The fish fillets wrapped in aluminium foil were placed on the steam tray and heated at 60 and $80{ }^{\circ} \mathrm{C}$, 
respectively, for $40 \mathrm{~min}$. The temperature was monitored by a K-type thermocouple temperature display product (Benetech, Model: GM1312, China), and it was placed in the centre of the fillet. Since at this temperature, the water was not in evaporation, then it was possible to control the temperature at 60 or $80{ }^{\circ} \mathrm{C}$.

\subsubsection{Electric oven cooking}

A Hamilton Beach Brands Inc. 31100 Large Countertop Convection Oven \& Rotisserie - Black, size 13.78" x 20.47" x 15.75" $(\mathrm{H} \times \mathrm{W} \times \mathrm{D})$, coated with fibreglass insulation was used for cooking the fish fillet by placing them on the metal tray. The temperature was set at 60 and $80{ }^{\circ} \mathrm{C}$, respectively, for 40 min, and the oven air velocity was $3 \mathrm{~m} \mathrm{~s}^{-1}$.

\subsubsection{Microwave cooking:}

LG® domestic oven model MH1449/00 (LG of Mexico), was used for cooking the fish fillets. Ceramic heating plate was used to cook the fillets for $10 \mathrm{~s}$ at two different powers (1400 and $140 \mathrm{~W}$ ). Cooking time was varied, depending on the microwave power applied.

\subsection{Proximal chemical analysis}

Proximal chemical analysis of fish slices was determined, based on the standard methods of the AOAC [20]: Total protein (Kjeldahl method 981.10); moisture (method 950.46); ash (method 938.08); total lipids (Soxhlet method 960.39) compared pre- and post-treatment with cooking methods.

\subsection{Physicochemical parameters}

The $a_{w}$ of each sample was measured using an AquaLab benchtop $a_{w}$ meter (Decagon Devices, Pullman WA, USA). To determine the $\mathrm{pH}$, the samples were first homogenised using a volume of 200 $\mathrm{mL}$ of distilled water for more than $1 \mathrm{~h}$, using a T18 digital Ultra-Turrax ${ }^{\circledR}$ homogeniser (Wilmington, NC 28405 USA). The pH value of each sample was then measured using a Hanna Instruments model 210 potentiometer; Aqua Technology Group (West Chester Township, OH, USA).

\subsection{Electrophoretic profile}

Samples were homogenised in a phosphate buffer, adjusting the $\mathrm{pH}$ of the mixture to 6.8 , then total protein was analysed using the Lowry method. A calibration curve was obtained using Bovine serum albumin as standard. Electrophoresis method was operated under denaturing conditions. The denatured samples were mixed with $\beta$-mercaptoethanol-sodium dodecyl sulphate-Tris buffer, glycerol and bromophenol blue, to achieve equivalent protein concentrations, loaded onto the gel and electrophoresed at 30 A per gel. A molecular weight (MW) standard was also loaded on the gel (Lane 1). Once the protein bands were separated, the gels were stained with Coomassie blue solution and then agitated in the methanol-acetic acid de-staining solution. A standard ultraviolet transilluminator gel imaging system was used to visualise the gel bands, allowing qualitative analysis of each protein detected.

\subsection{Fatty acids profile}

Soxhlet method was used to extract the total lipids from the fish fillet samples. The solvent was removed using a Rotavapor R-210 (Büchi Labortechnik AG, Germany). The samples were placed in different test tubes for the subsequent methylation and determination. FA esterification was performed

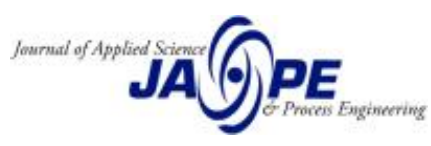


at $60{ }^{\circ} \mathrm{C}$ for $2 \mathrm{~h}$, by mixing $100 \mu \mathrm{L}$ of sample and $1 \mathrm{~mL}$ of $1 \mathrm{~N}$ methanolic- $\mathrm{HCl}$ solution. The derivatization reaction was accomplished by adding $100 \mu \mathrm{L}$ of water. Thus, $2 \mathrm{~mL}$ of hexane was added to the methylated ester to have the final solution for analysis. Then, one $\mu \mathrm{L}$ of this sample was analysed by GC chromatograph (Hewlett-Packard, model 6890 Palo Alto, CA) equipped with a flame ionisation detector and Supelcowax-10 capillary column $(30 \mathrm{~m} \times 0.25 \mathrm{~mm}, 0.25 \mu \mathrm{m}$ film thickness) [21]. The methyl ester was eluted from the column heated initially during $7 \mathrm{~min}$ at a temperature of $170{ }^{\circ} \mathrm{C}$, and then constantly increased at a rate of $4{ }^{\circ} \mathrm{C} \mathrm{min}^{-1}$ to $210{ }^{\circ} \mathrm{C}$ and maintained for another $5 \mathrm{~min}$ and, finally, further increased to $230{ }^{\circ} \mathrm{C}$ and maintained for $18 \mathrm{~min}$. The temperature of the injection port and the detector were set at 300 and $250{ }^{\circ} \mathrm{C}$, respectively. Nitrogen was the carrier gas and supplied at a constant

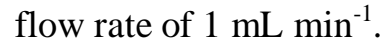

\subsection{Experimental design and statistical analysis}

To analyse the effect of different cooking methods on the nutritional properties of Tilapia, a completely randomised factorial design of three treatments with two replicates was employed. The treatments included (i) electric oven cooking (60 and $80{ }^{\circ} \mathrm{C}$ ), (ii) steaming (60 and $80{ }^{\circ} \mathrm{C}$ ) and (iii) microwave oven cooking $(140$ and $1400 \mathrm{~W})$. The selected-response variables were the percentage of protein, lipid, ash, moisture, $\mathrm{a}_{\mathrm{w}}$ and $\mathrm{pH}$ values. ANOVA using the Mini-Tab® program 16.2.2 (Minitab, LLC Pennsylvania, USA) was used to evaluate the experimental results statistically.

\section{Results and discussion}

\subsection{Effect of the cooking methods on nutritional quality}

The chemical composition of fish meat mainly depends on factors, like the species, age, physiological state, and time and region of capture. Mature fish are generally richer in fat and, therefore, will have a lower content of water than the juveniles. Some seasonal fish are thinner, and their meat contains a higher amount of water with less protein and fat than non-seasonal fish [22].

There were significant differences $(\mathrm{P}<0.05)$ in the protein, lipid, moisture, ash, $\mathrm{a}_{\mathrm{w}}$ and $\mathrm{pH}$ among the cooking methods (Table 1). A reduction in protein content was observed compared with the control (fresh sample). These results were similar to those reported for Tilapia confirming the accurateness of the finding of this research [9-10]. Still, they differed from those attained when investigating the effect of three different conventional cooking methods on the proximate composition, mineral and fatty acid profile of catfish fillets (Ictalurus punctatus, Rafinesque) thereby highlighting the influence of the fish species [23].

The trend in protein reduction after cooking was observed for all three cooking methods. Microwave cooking $(140 \mathrm{~W})$ had the least impact (19.90 $\pm 0.13 \%$ protein) while electric oven cooking at $80{ }^{\circ} \mathrm{C}$ caused the most significant effect $(14.50 \pm 0.03 \%$ protein). The decrease was due to the high temperature $\left(60\right.$ and $\left.80^{\circ} \mathrm{C}\right)$ and power $(140$ and $1400 \mathrm{~W})$ conditions, as well as the long treatment time, which led to denaturation of the proteins present in the original Tilapia samples. This outcome was further verified by the presence of specific protein bands in the electrophoretic analysis, as described below (section 3.2). It has been reported that the lipid concentration increased irrespective to the cooking methods $[10,13]$ as it was found in this research. The reason for the lipid increment was mainly due to the high temperatures used, which can extract the lipids from deep within the tissue of the Tilapia samples. This effect was evident at 60 and $80{ }^{\circ} \mathrm{C}$ for steam, electric oven and microwave $(1400 \mathrm{~W})$ cooking. The highest lipid content was obtained through the electric oven cooking method at 60 and 80 ${ }^{\circ} \mathrm{C}$ while microwave cooking at $140 \mathrm{~W}$ and steaming at $60{ }^{\circ} \mathrm{C}$ extracted the least lipid content from the Tilapia samples. An increase in ash content (minerals and salts) was noticed across all the cooking methods, except steaming, which probably deteriorated the interactions between minerals and proteins during the heat treatment (steaming) of the Tilapia samples.

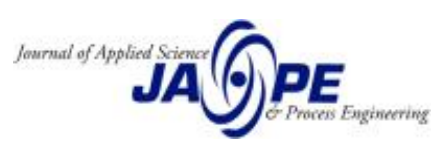


Table 1. Effect of cooking methods on the proximal composition $(\mathrm{g} / 100 \mathrm{~g})$ (wet basis) of Tilapia.

\begin{tabular}{lcccccc}
\hline Equipment & Protein $(\%) \S$ & Lipids (\%) & Ash (\%) & Moisture $(\%)$ & $\mathrm{a}_{\mathrm{w}}$ & $\mathrm{pH}$ \\
\hline Control & $22.2 \pm 0.040 \mathrm{a}$ & $1.3 \pm 0.010 \mathrm{f}$ & $1.1 \pm 0.008 \mathrm{e}$ & $78.1 \pm 0.180 \mathrm{a}$ & $0.98 \pm 0.008 \mathrm{a}$ & $6.64 \pm 0.008 \mathrm{~b}$ \\
\hline Microwave $($ Watt $)$ & & & & & \\
\hline 140 & $19.9 \pm 0.130 \mathrm{~b}$ & $1.5 \pm 0.010 \mathrm{e}$ & $1.2 \pm 0.008 \mathrm{~d}$ & $65.1 \pm 0.210 \mathrm{~d}$ & $0.96 \pm 0.008 \mathrm{~b}$ & $6.75 \pm 0.008 \mathrm{a}$ \\
1400 & $19.1 \pm 0.020 \mathrm{c}$ & $2.0 \pm 0.008 \mathrm{c}$ & $1.3 \pm 0.008 \mathrm{c}$ & $59.5 \pm 0.140 \mathrm{e}$ & $0.91 \pm 0.008 \mathrm{~d}$ & $6.64 \pm 0.008 \mathrm{~b}$ \\
\hline Steam $\left({ }^{\circ} \mathrm{C}\right)$ & & & & & & \\
\hline 60 & $18.1 \pm 0.040 \mathrm{~d}$ & $1.6 \pm 0.004 \mathrm{e}$ & $1.1 \pm 0.008 \mathrm{f}$ & $78.6 \pm 0.010 \mathrm{a}$ & $0.97 \pm 0.008 \mathrm{a}$ & $6.50 \pm 0.008 \mathrm{c}$ \\
80 & $17.86 \pm 0.040 \mathrm{e}$ & $1.9 \pm 0.004 \mathrm{~d}$ & $1.0 \pm 0.008 \mathrm{f}$ & $76.0 \pm 0.220 \mathrm{~b}$ & $0.93 \pm 0.008 \mathrm{c}$ & $6.73 \pm 0.008^{\mathrm{a}}$ \\
\hline Oven $\left({ }^{\circ} \mathrm{C}\right)$ & & & & & & \\
\hline 60 & $16.2 \pm 0.010 \mathrm{f}$ & $4.3 \pm 0.004 \mathrm{~b}$ & $1.4 \pm 0.020 \mathrm{~b}$ & $67.2 \pm 0.180 \mathrm{c}$ & $0.95 \pm 0.008 \mathrm{~b}$ & $6.74 \pm 0.008 \mathrm{a}$ \\
80 & $14.5 \pm 0.030 \mathrm{~g}$ & $4.8 \pm 0.010 \mathrm{a}$ & $1.8 \pm 0.008 \mathrm{a}$ & $58.5 \pm 0.310 \mathrm{f}$ & $0.93 \pm 0.008 \mathrm{c}$ & $6.63 \pm 0.008 \mathrm{~b}$ \\
\hline
\end{tabular}

Measurements with different letters in one row are statistically different (ANOVA, $\mathrm{p} \leq 0.05$ ).

${ }^{\S}$ Calculated using a factor of 6.25 .

Increasing the temperature during the cooking process decreases the water content, fat and protein in fish [3]. The denaturation of the proteins during the cooking will result in evaporation of water molecules and thereby less water content in the structures of the proteins. All the cooking methods reduced the overall moisture content in the Tilapia samples, except steaming at $60{ }^{\circ} \mathrm{C}$, suggesting the microwaved and electric oven-cooked fillets may have an increased preservation time. Furthermore, the greatest decrease in the $\mathrm{a}_{\mathrm{w}}$ was observed following electric oven cooking at $80{ }^{\circ} \mathrm{C}$, microwave cooking at $1400 \mathrm{~W}$ and steaming at $80{ }^{\circ} \mathrm{C}$, respectively. The $\mathrm{a}_{\mathrm{w}}$ of a particular food is the ratio between the vapour pressure of the studied food, when in a completely undisturbed balance with the surrounding air media, and the vapour pressure of distilled water under identical conditions. The water present in the Tilapia samples will react chemically with other substances and lead to bacterial growth; hence, a lower value of $a_{w}$ is preferable. A significant decrease in $a_{w}$ was observed $(p<0.05)$, especially when the Tilapia fillets were cooked in the microwave at $1400 \mathrm{~W}$, resulting in the lowest $\mathrm{a}_{\mathrm{w}}$ value.

Besides the influence of water content, food-borne pathogenic bacteria prefer to grow at a neutral to alkaline $\mathrm{pH}$ and $37{ }^{\circ} \mathrm{C}$. Foods with a low $\mathrm{pH}(<4.5)$ inhibit the growth of pathogens, such as Clostridium botulinum and Staphylococcus aureus. As a result of the significant difference $(\mathrm{p}<0.05)$ in the $\mathrm{pH}$ between the control and treated Tilapia fillets, the cooked samples inhibit the growth of pathogens.

\subsection{Effect of cooking methods on the electrophoretic profile}

The electrophoretic profiles of the cooked and control samples are shown in Figure 1. The presence of each band represents a protein/peptide of a particular MW. Therefore, proteins of different MWs are different proteins. Compared with the control (standard MW mixture), some bands were absent, probably due to protein modification (e.g., denaturation, hydrolysis) as a result of the high cooking temperatures adopted. At the 3-dimensional structural level, the meat proteins may denature and form aggregates upon high-temperature heating. At the molecular level, the primary structure (amino acid sequence) can undergo alterations, such as protein carbonylation and modification of aromatic residues, and the formation of Maillard reaction products may occur during the cooking [24]. Seven different bands with MWs of 22, 38, 48, 65, 70, 110 and $120 \mathrm{kDa}$, respectively, were detected in 
control. Electric oven cooking at 60 and $80{ }^{\circ} \mathrm{C}$ resulted in the detection of only two (22 and $100 \mathrm{kDa}$ ) and three protein bands $(22,38$ and $110 \mathrm{kDa})$, respectively. In contrast, five protein bands were evident after steaming at $60{ }^{\circ} \mathrm{C}(22,48,65,97$ and $110 \mathrm{kDa})$, whereas this was reduced to three protein bands $(22,70$ and $110 \mathrm{kDa})$ when steam-cooked at $80{ }^{\circ} \mathrm{C}$. The four protein bands observed after microwave cooking at $140 \mathrm{~W}(22,50,82$ and $110 \mathrm{kDa})$ were similar in MW to those found in the samples treated at $1400 \mathrm{~W}(22,48,65$ and $110 \mathrm{kDa})$.

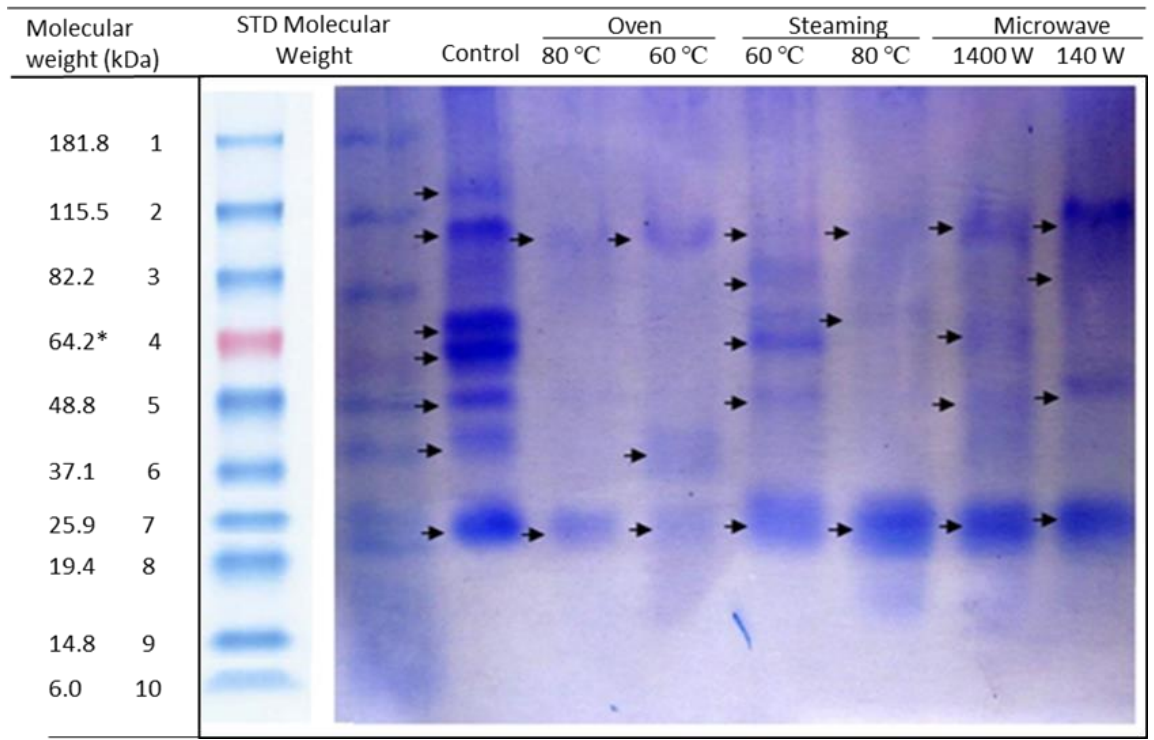

Figure 1. Electrophoretic pattern of Tilapia samples treated by three cooking methods.

It was found that the colour intensity and thickness of several bands decreased because the proteins differ in their susceptibility to heat stress. Microwaving at $140 \mathrm{~W}$ for $10 \mathrm{~s}$ reduced the protein content in the Tilapia samples by $\sim 30 \%$, through molecular vibration. Thereby, the intensity of the microwave thermal radiation denatured the protein components in the Tilapia samples compared with the steaming and electric oven cooking methods. Microwave radiation can alter protein conformation. For instance, it has been demonstrated to enhance the aggregation of bovine serum albumin and promote amyloid fibril formation at $60{ }^{\circ} \mathrm{C}$ [25]. These protein alterations are not the result of high temperature but rather the microwave radiation [26]. Thus, it is essential to check whether the cooking time used in this study $(10 \mathrm{~s})$ can maintain the highest percentage of proteins when using this approach. Also, performing two-dimensional electrophoresis would help to determine which protein groups are denatured by the steaming and electric oven cooking methods.

\subsection{Effect of cooking methods on the fatty acid profile}

Tables 2, 3 and 4 show the average amounts of each fatty acid characterised in the fresh and cooked Tilapia fillets. There were 21 fatty acids identified in total, including 4 saturated fatty acids (SFA) and 17 UFA. In an earlier investigation of three separate freshwater fish species (Carp, Nile Tilapia and Tambacu) under different storage and cooking processes, the storage and cooking methods used did not interfere with the fatty acid composition [11].

Electric oven cooking at $60{ }^{\circ} \mathrm{C}$ led to an increment of $12 \%$ in the SFA in the Tilapia fillets compared with the control, whereas, at $80{ }^{\circ} \mathrm{C}$, a $13 \%$ increment in the SFA occurred. The concentration of myristic acid (C14:0) was found to be $95 \%$ higher at $60{ }^{\circ} \mathrm{C}$ and $118 \%$ higher at $80{ }^{\circ} \mathrm{C}$ in comparison to the control. The total concentration of UFA increased by $\sim 16 \%$ and $20 \%$ at 60 and $80^{\circ} \mathrm{C}$, respectively. Palmitoleic acid (C16:1 $\omega-7)$ was the major fatty acid present in Tilapia. Whereas arachidonic acid 
(C20:4 $\omega-6)$ and EPA (C20:5 $\omega-3)$ decreased slightly at both temperatures, DHA (22:6 $\omega-3)$ increased by $44 \%$ and $14 \%$ at 60 and $80{ }^{\circ} \mathrm{C}$, respectively. At $60{ }^{\circ} \mathrm{C}$, an increment of $54 \%$ in the total concentration of $\omega-3$ fatty acids was determined, and a slight reduction of $48 \%$ was noticed at $80{ }^{\circ} \mathrm{C}$. Gladyshev et al., (2006) reported a similar trend for $\omega-6$ fatty acids [27], showing the consistency with the findings 
Table 2. Effect of electric convective oven cooking method on the concentration of fatty acids $(\mathrm{g} / 100 \mathrm{~g})$

\begin{tabular}{|c|c|c|c|c|}
\hline \multirow{2}{*}{ Fatty Acid } & & \multicolumn{3}{|c|}{ Electric convective oven treatment } \\
\hline & & Control & $60^{\circ} \mathrm{C}$ & $80^{\circ} \mathrm{C}$ \\
\hline \multicolumn{5}{|l|}{ Saturated } \\
\hline Lauric & C12:0 & $1.13 \pm 0.012^{\mathrm{a}}$ & $0.39 \pm 0.001^{\mathrm{b}}$ & $0.18 \pm 0.05^{\mathrm{c}}$ \\
\hline Myristic & C $14: 0$ & $2.73 \pm 0.028^{c}$ & $5.42 \pm 0.49^{b}$ & $6.06 \pm 0.05^{\mathrm{a}}$ \\
\hline Palmitic & C $16: 0$ & $21.91 \pm 0.057^{\mathrm{c}}$ & $26.82 \pm 0.22^{b}$ & $27.47 \pm 0.28^{\mathrm{a}}$ \\
\hline Estearic & C $18: 0$ & $7.30( \pm 0.083)^{\mathrm{a}}$ & $4.67 \pm 0.12^{b}$ & $3.81 \pm 0.1^{\mathrm{c}}$ \\
\hline$\Sigma$ & & 33.11 & 36.95 & 37.52 \\
\hline \multicolumn{5}{|l|}{ Unsaturated } \\
\hline Palmitoleic & C16:1 n-7 & $2.40 \pm 0.08^{\mathrm{c}}$ & $14.455 \pm 0.10^{\mathrm{b}}$ & $16.28 \pm 0.162^{\mathrm{a}}$ \\
\hline Sapienic & C16:1 n-10 & $4.72 \pm 0.188^{\mathrm{a}}$ & ND & ND \\
\hline Oleic acid & C18:1 n-9 & $10.34 \pm 0.040^{\mathrm{a}}$ & $8.12 \pm 0.039^{c}$ & $8.73 \pm 0.075^{\mathrm{b}}$ \\
\hline Vaccenic & C18:1 n-7 & $3.31 \pm 0.384^{\mathrm{a}}$ & $3.59 \pm 0.018^{\mathrm{a}}$ & $3.71 \pm 0.046^{\mathrm{a}}$ \\
\hline Linoleic & C18:2 n-6 & $3.39 \pm 0.037^{\mathrm{c}}$ & $3.92 \pm 0.049^{\mathrm{a}}$ & $3.77 \pm 0.051^{\mathrm{b}}$ \\
\hline Linolenic & $\mathrm{C} 18: 3 \mathrm{n}-3$ & $1.95 \pm 0.020^{\mathrm{c}}$ & $4.10 \pm 0.019^{b}$ & $4.61 \pm 0.005^{\mathrm{a}}$ \\
\hline Octadecatetraenoic & C18:4 n-3 & $1.11 \pm 0.008^{b}$ & $1.14 \pm 0.007^{\mathrm{a}}$ & $0.71 \pm 0.013^{\mathrm{c}}$ \\
\hline Eicosanoic & C20:1 n-9 & $0.50 \pm 0.011^{\mathrm{a}}$ & $0.29 \pm 0.001^{\mathrm{b}}$ & $0.30 \pm 0.007^{b}$ \\
\hline Eicosadienoic & $C 20: 2 n-6$ & $1.27 \pm 0.041^{\mathrm{a}}$ & $0.40 \pm 0.007^{\mathrm{b}}$ & $0.30 \pm 0.015^{\mathrm{c}}$ \\
\hline Arachidonic & C20:4 n-6 & $2.49 \pm 0.217^{\mathrm{a}}$ & $1.69 \pm 0.019^{\mathrm{b}}$ & $1.26 \pm 0.053^{c}$ \\
\hline Eicosatetraenoic & C20:4 n-3 & $1.08 \pm 0.138^{\mathrm{a}}$ & $0.51 \pm 0.007^{\mathrm{b}}$ & $0.55 \pm 0.080^{\mathrm{b}}$ \\
\hline Eicosapentaenoic & C20:5 n-3 (EPA) & $0.94 \pm 0.041^{\mathrm{a}}$ & $0.74 \pm 0.008^{\mathrm{b}}$ & $0.58 \pm 0.055^{\mathrm{c}}$ \\
\hline Ericic & C22:1 n-9 & $1.61 \pm 0.693^{\mathrm{a}}$ & $0.28 \pm 0.004^{\mathrm{b}}$ & $0.13 \pm 0.012^{\mathrm{b}}$ \\
\hline Adrenic & C22:4 n-6 & ND & $0.37 \pm 0.046^{\mathrm{b}}$ & $0.44 \pm 0.015^{\mathrm{a}}$ \\
\hline Docosapentaenoic & $c-22: 5 n-6$ & ND & $0.40 \pm 0.001^{\mathrm{b}}$ & $0.50 \pm 0.017^{\mathrm{a}}$ \\
\hline Docosapentaenoic & $\mathrm{C} 22: 5$ n-3 (DPA) & $0.41 \pm 0.016^{\mathrm{b}}$ & $1.49 \pm 0.028^{\mathrm{a}}$ & $1.43 \pm 0.056^{\mathrm{a}}$ \\
\hline Docosahexaenoic & $\mathrm{C} 22: 6$ n-3 (DHA) & $1.78 \pm 0.016^{\mathrm{c}}$ & $2.56 \pm 0.013^{\mathrm{a}}$ & $2.04^{\mathrm{b}} \pm 0.006^{\mathrm{b}}$ \\
\hline$\Sigma$ & & 37.70 & 44.049 & 45.342 \\
\hline$\Sigma \omega-3$ & & 6.33 & 9.799 & 9.345 \\
\hline$\Sigma \omega-6$ & & 7.15 & 6.774 & 6.264 \\
\hline
\end{tabular}

of this research. A similar increment in the lipid content of fatty acids after cooking was demonstrated as well by other researchers [11-13]. This tendency could be a result of the additional oil evenly in the sample during cooking, and this has resulted in a greater likelihood to arise the lipids of the sample, especially from the skin tissue. However, it is well known that heating will lead to hydrolysis and oxidation of lipids [28].

The total concentration of the SFA increased $25 \%$, and the concentration of palmitic acid in the Tilapia sample was the highest $(30 \%)$ using microwave cooking at $1400 \mathrm{~W}$. These heating conditions also increased the total concentration of the UFA by $13 \%$ when compared with the control. The strongest UFA peaks in the microwaved Tilapia fillet cooked at $1400 \mathrm{~W}$ corresponded to sapienic acid (C16:1

* Corresponding author. Tel.: +52-281-872 9230; fax: +52-281-872 9230

E-mail address: cnolasco36@gmail.com.

Manuscript History:

Received 11 March, 2020, Revised 24 April, 2020, Accepted 29 April, 2020, Published 30 April, 2020 
$\omega-10 ; 121 \%)$, arachidonic acid (C20:4 $\omega-6 ; 214 \%)$, eicosatetraenoic acid (C20:4 $\omega-3 ; 42 \%)$, EPA (C20:5 $\omega-3 ; 225 \%)$, erucic acid (C22:1 $\omega-9 ; 67 \%)$ and DHA $(22: 6 \omega-3 ; 43 \%)$, respectively.

Finally, the concentration of lipids recorded in steamed Tilapia is provided in Table 4. Four UFA were present in control and cooked samples $\left(60\right.$ and $\left.80^{\circ} \mathrm{C}\right)$, namely, lauric acid (C12:0)), myristic acid (C14:0), palmitic acid (C16:0) and stearic acid (C18:0). The amount of myristic acid (C14:0) increased by $\sim 12 \%$ and $34 \%$ at 60 and $80{ }^{\circ} \mathrm{C}$, respectively, after cooking. There was an increase of $2.6 \%$ in the concentration of SFA at $60{ }^{\circ} \mathrm{C}$ but a slight decrease at $80{ }^{\circ} \mathrm{C}$ when compared with the control. A significant increase of $2.8 \%$ was noted in the total UFA concentration when cooked at $60{ }^{\circ} \mathrm{C}$; at $80{ }^{\circ} \mathrm{C}$, it was further increased to $10 \%$. Arachidonic acid (C20:4 $\omega-6)$ increased by $11 \%$ at $80^{\circ} \mathrm{C}$ but decreased slightly at $60^{\circ} \mathrm{C}$. An increase of $13 \%$ and 52\% EPA (C20:5 $\left.\omega-3\right)$ and $27 \%$ and $19 \%$ DHA (C22:6 $\left.\omega-3\right)$ was apparent at 60 and $80{ }^{\circ} \mathrm{C}$, respectively. The steaming and microwave oven processes data indicate that these are the most desirable methods to cook Tilapia, from a nutritional perspective if the consumer wants to take advantage of the protein content only.

Table 3. Effect of microwave oven cooking method on the concentration of fatty acids $(\mathrm{g} / 100 \mathrm{~g})$ in Tilapia.

\begin{tabular}{|c|c|c|c|c|}
\hline \multirow{2}{*}{\multicolumn{2}{|c|}{ Fatty Acid }} & \multicolumn{3}{|c|}{ Microwave oven cooking method (Watts) } \\
\hline & & Control & 140 & 1400 \\
\hline \multicolumn{5}{|l|}{ Saturated } \\
\hline Lauric & $\mathrm{C} 12: 0$ & $0.97 \pm 0.053^{\mathrm{a}}$ & $1.00 \pm 0.213^{\mathrm{a}}$ & $0.83 \pm 0.009^{\mathrm{a}}$ \\
\hline Myristic & $\mathrm{C} 14: 0$ & $2.70 \pm 0.0249^{\mathrm{a}}$ & $2.51 \pm 0.111^{\mathrm{b}}$ & $2.53 \pm 0.024^{\mathrm{b}}$ \\
\hline Palmitic & $\mathrm{C} 16: 0$ & $17.83 \pm 0.147^{\mathrm{b}}$ & $17.07 \pm 0.645^{\mathrm{b}}$ & $23.230 \pm 0.228^{\mathrm{a}}$ \\
\hline Estearic & C18:0 & $6.26 \pm 0.027^{\mathrm{b}}$ & $5.82 \pm 0.148^{c}$ & $8.03 \pm 0.072^{\mathrm{a}}$ \\
\hline$\Sigma$ & & 27.76 & 26.40 & 34.69 \\
\hline \multicolumn{5}{|l|}{ Unsaturated } \\
\hline Palmitoleic & C16:1 n-7 & $1.54 \pm 0.014^{\mathrm{b}}$ & $1.281 \pm 0.009^{\mathrm{c}}$ & $1.63 \pm 0.008^{\mathrm{a}}$ \\
\hline Sapienic & C16:1 n-10 & $2.33 \pm 0.0160^{\mathrm{b}}$ & $2.08 \pm 0.038 b$ & $5.15 \pm 0.618 a$ \\
\hline Oleic acid & C18:1 n-9 & $10.26 \pm 0.045^{\mathrm{a}}$ & $7.42 \pm 0.034^{\mathrm{b}}$ & $7.34 \pm 0.056^{\mathrm{b}}$ \\
\hline Vaccenic & C18:1 n-7 & $1.54 \pm 0.036^{\mathrm{a}}$ & $1.69 \pm 0.633^{\mathrm{a}}$ & $1.89 \pm 0.055^{\mathrm{a}}$ \\
\hline Linoleic & C18:2 n-6 & $2.41 \pm 0.027^{\mathrm{b}}$ & $2.40 \pm 0.120^{\mathrm{b}}$ & $3.49 \pm 0.030^{\mathrm{a}}$ \\
\hline Linolenic & C18:3 n-3 & $2.68 \pm 0.034^{\mathrm{a}}$ & $1.80 \pm 0.082^{\mathrm{c}}$ & $2.38 \pm 0.065^{\mathrm{b}}$ \\
\hline Octadecatetraenoic & C18:4 n-3 & $2.56 \pm 0.0217^{\mathrm{b}}$ & $3.44 \pm 0.158^{\mathrm{a}}$ & $1.78 \pm 0.019^{c}$ \\
\hline Eicosanoic & C20:1 n-9 & $0.32 \pm 0.0197^{b}$ & $0.48 \pm 0.042^{\mathrm{a}}$ & $0.44 \pm 0.016^{\mathrm{a}}$ \\
\hline Eicosadienoic & $C 20: 2 n-6$ & $6.54 \pm 0.200^{\mathrm{b}}$ & $8.61 \pm 0.361^{\mathrm{a}}$ & $1.94 \pm 0.019^{\mathrm{c}}$ \\
\hline Arachidonic & $C 20: 4 n-6$ & $1.14 \pm 0.0142^{c}$ & $1.38 \pm 0.074^{\mathrm{b}}$ & $3.57 \pm 0.050^{\mathrm{a}}$ \\
\hline Eicosatetraenoic & $C 20: 4 n-3$ & $0.78 \pm 0.258^{\mathrm{b}}$ & $0.78 \pm 0.053^{\mathrm{b}}$ & $1.11 \pm 0.022^{\mathrm{a}}$ \\
\hline EicosapentaenoiC & $\begin{array}{c}\text { C20:5 n-3 } \\
\text { (EPA) }\end{array}$ & $0.39 \pm 0.160^{\mathrm{b}}$ & $0.50 \pm 0.021^{\mathrm{b}}$ & $1.28 \pm 0.036^{\mathrm{a}}$ \\
\hline Euricic & $\mathrm{C} 22: 1 \mathrm{n}-9$ & $0.67 \pm 0.129^{c}$ & $0.84 \pm 0.030 b$ & $1.12 \pm 0.028^{\mathrm{a}}$ \\
\hline Adrenic & $\mathrm{C} 22: 4 \mathrm{n}-6$ & ND & ND & ND \\
\hline Docosapentaenoic & $C-22: 5 n-6$ & ND & ND & $0.681 \pm 0.009 \mathrm{a}$ \\
\hline Docosapentaenoic & $\begin{array}{c}\text { C22:5 n-3 } \\
\text { (DPA) }\end{array}$ & $0.28 \pm 0.081^{\mathrm{c}}$ & $0.48 \pm 0.020^{\mathrm{b}}$ & $1.00 \pm 0.018^{\mathrm{a}}$ \\
\hline Docosahexaenoic & $\begin{array}{l}\text { C22:6 n-3 } \\
\text { (DHA) }\end{array}$ & $1.00 \pm 0.007^{\mathrm{c}}$ & $1.67 \pm 0.065^{\mathrm{b}}$ & $5.33 \pm 0.038^{\mathrm{a}}$ \\
\hline$\Sigma$ & & 34.46 & 34.88 & 39.12 \\
\hline
\end{tabular}




\begin{tabular}{cccc}
$\Sigma \omega-3$ & 7.31 & 8.19 & 11.59 \\
$\Sigma \omega-6$ & 10.09 & 12.39 & 9.69 \\
\hline
\end{tabular}

Table 4. Effect of steaming cooking method on the concentration of fatty acids $(\mathrm{g} / 100 \mathrm{~g})$ in Tilapia.

\begin{tabular}{|c|c|c|c|c|}
\hline \multirow{2}{*}{\multicolumn{2}{|c|}{ Fatty Acid }} & \multirow[b]{2}{*}{ Control } & \multicolumn{2}{|c|}{ Steaming cooking method $\left({ }^{\circ} \mathbf{C}\right)$} \\
\hline & & & $60^{\circ} \mathrm{C}$ & $80^{\circ} \mathrm{C}$ \\
\hline \multicolumn{5}{|l|}{ Saturated } \\
\hline Lauric & C12:0 & $0.42 \pm 0.006^{\mathrm{a}}$ & $0.28 \pm 0.008^{\mathrm{b}}$ & $0.23 \pm 0.054^{\mathrm{b}}$ \\
\hline Myristic & $\mathrm{C} 14: 0$ & $5.72 \pm 0.050^{c}$ & $6.40 \pm 0.082^{\mathrm{b}}$ & $7.70 \pm 0.040^{\mathrm{a}}$ \\
\hline Palmitic & C16:0 & $24.49 \pm 0.289^{\mathrm{a}}$ & $24.72 \pm 0.301^{\mathrm{a}}$ & $23.64 \pm 0.098^{\mathrm{b}}$ \\
\hline Estearic & C18:0 & $5.46 \pm 0.065^{\mathrm{a}}$ & $5.64 \pm 0.281^{\mathrm{a}}$ & $3.88 \pm 0.041^{\mathrm{b}}$ \\
\hline$\Sigma$ & & 36.091 & 37.038 & 35.464 \\
\hline \multicolumn{5}{|l|}{ Unsaturated } \\
\hline Palmitoleic & C16:1 n-7 & $13.86 \pm 0.157^{\mathrm{c}}$ & $14.75 \pm 0.161^{\mathrm{b}}$ & $17.42 \pm 0.099^{\mathrm{a}}$ \\
\hline Sapienic & C16:1 n-10 & ND & ND & ND \\
\hline Oleic acid & C18:1 n-9 & $7.09 \pm 0.042^{\mathrm{a}}$ & $6.20 \pm 0.115^{\mathrm{b}}$ & $5.38 \pm 0.001^{\mathrm{c}}$ \\
\hline Vaccenic & C18:1 n-7 & $3.22 \pm 0.039^{\mathrm{a}}$ & $3.16 \pm 0.014^{\mathrm{a}}$ & $3.02 \pm 0.051^{b}$ \\
\hline Linoleic & C18:2 n-6 & $4.13 \pm 0.038^{a}$ & $3.85 \pm 0.056^{\mathrm{b}}$ & $3.79 \pm 0.056^{b}$ \\
\hline Linolenic & C18:3 n-3 & $3.32 \pm 0.026^{c}$ & $3.70 \pm 0.033^{\mathrm{b}}$ & $4.28 \pm 0.046^{\mathrm{a}}$ \\
\hline Octadecatetraenoic & C18:4 n-3 & $1.74 \pm 0.002^{\mathrm{b}}$ & $2.01 \pm 0.005^{\mathrm{a}}$ & $1.56 \pm 0.009^{c}$ \\
\hline Eicosanoic & C20:1 n-9 & $0.26 \pm 0.007^{\mathrm{a}}$ & ND & $0.18 \pm 0.015^{\mathrm{b}}$ \\
\hline Eicosadienoic & $C 20: 2 n-6$ & $0.84 \pm 0.061^{\mathrm{a}}$ & $0.66 \pm 0.003^{\mathrm{b}}$ & $0.30 \pm 0.014^{\mathrm{c}}$ \\
\hline Arachidonic & C20:4 n-6 & $1.71 \pm 0.091^{\mathrm{a}}$ & $1.69 \pm 0.008^{\mathrm{a}}$ & $1.89 \pm 0.176^{\mathrm{a}}$ \\
\hline Eicosatetraenoic & C20:4 n-3 & $0.93 \pm 0.027^{\mathrm{c}}$ & $1.14 \pm 0.134^{\mathrm{b}}$ & $1.65 \pm 0.032^{\mathrm{a}}$ \\
\hline EicosapentaenoiC & C20:5 n-3 (EPA) & $0.97 \pm 0.007^{\mathrm{b}}$ & $1.10 \pm 0.136^{\mathrm{b}}$ & $1.49 \pm 0.028^{\mathrm{a}}$ \\
\hline Euricic & $\mathrm{C} 22: 1 \mathrm{n}-9$ & $0.58 \pm 0.072^{\mathrm{a}}$ & $0.44 \pm 0.072^{\mathrm{b}}$ & $0.43 \pm 0.009^{b}$ \\
\hline Adrenic & C22:4 n-6 & $0.39 \pm 0.006^{\mathrm{b}}$ & $0.40 \pm 0.008^{\mathrm{b}}$ & $0.63 \pm 0.063^{\mathrm{a}}$ \\
\hline Docosapentaenoic & $C-22: 5 n-6$ & $0.48 \pm 0.002^{\mathrm{c}}$ & $0.59 \pm 0.066^{\mathrm{b}}$ & $0.98 \pm 0.019^{\mathrm{a}}$ \\
\hline Docosapentaenoic & $\mathrm{C} 22: 5$ n-3 (DPA) & $1.91 \pm 0.007^{\mathrm{c}}$ & $2.35 \pm 0.072^{\mathrm{b}}$ & $2.54 \pm 0.040^{\mathrm{a}}$ \\
\hline Docosahexaenoic & C22:6 n-3 (DHA) & $2.27 \pm 0.011^{\mathrm{c}}$ & $2.91 \pm 0.118^{a}$ & $2.75 \pm 0.057^{b}$ \\
\hline$\Sigma$ & & 43.72 & 44.92 & 48.24 \\
\hline$\Sigma \omega-3$ & & 10.18 & 12.12 & 14.22 \\
\hline$\Sigma \omega-6$ & & 7.55 & 7.19 & 7.59 \\
\hline
\end{tabular}

\section{Conclusion}

This study demonstrated that the nutritional properties of cooked Tilapia fillets are affected by the type of cooking method applied. Based on the quantity of protein and lipid preserved, the moisture content, aw and $\mathrm{pH}$, the most efficient mode of cooking is in the microwave convective oven at 1400 $\mathrm{W}$. Microwave oven cooking at $1400 \mathrm{~W}$ can retain the nutritional properties in the Tilapia fish compared with steaming and electric oven cooking. Further consideration should be given to the processes or instrument and utility costs in further studies since these factors will also influence the cooking technique chosen by the consumer/industry. 


\section{References}

[1] Shahidi, F. and Ambigaipalan, P. (2018). Omega-3 Polyunsaturated Fatty Acids and Their Health Benefits. Annu Rev Food Sci Technol; Vol.9, 345-381.

[2] USDA \& HHS. (2010). Dietary guidelines for Americans, Washington, DC: U.S. Department of Agriculture and the U.S. Department of Health and Human Services.

[3] Brugiapaglia, A. and Destefanis, G. (2012). Effect of Cooking Method on the Nutritional Value of Piemontese Beef. In P. J. Shand (Ed.), Proceedings of the 58th International Congress of Meat Science and Technology-ICoMST 2012, NUTRIENTP-5, Saskatoon, Canada: University of Saskatchewan.

[4] Clausen, I. and Ovesen, L. (2005). Changes in Fat Content of Pork and Beef After Pan-Frying under Different Conditions. J Food Compos Anal, Vol. 18. No. 2-3, 201-211.

[5] Jiang, Q., Han, J., Gao, P., Yu, L., Xu, Y. and Xia, W. (2018). Effect of Heating Temperature and Duration on the Texture and Protein Composition of Bighead Carp (Aristichthys nobilis) Muscle, Int J Food Prop, Vol. 21, No.1, 2110-2120.

[6] Domínguez, R., Gómez, M., Fonseca, S. and Lorenzo, J.M. (2014). Effect of Different Cooking Methods on Lipid Oxidation and Formation of Volatile Compounds in Foal Meat, Meat Sci; Vol.97, No.2, 223-230.

[7] Alfaia, C.M., Alves, S.P., Lopes, A.F., Fernandes, M.J., Costa, A.S.., Fontes, C.M. and Prates, J.A. (2010). Effect of Cooking Methods on Fatty Acids, Conjugated Isomers of Linoleic Acid and Nutritional Quality of Beef Intramuscular Fat. Meat Sci, Vol.84, No.4, 769-777.

[8] Broncano, J.M., Petrón, M.J., Parra, V. and Timón, M.L. (2009). Effect of Different Cooking Methods on Lipid Oxidation and Formation of Free Cholesterol Oxidation Products (COPs) in Latissimus Dorsi Muscle of Iberian Pigs, Meat Sci; Vol.83, No.3, 431-437.

[9] Abdul-Hamid, A., Bakar, J. and Bee, G.H. (2002). Nutritional Quality of Spray Dried Protein Hydrolysate From Black Tilapia (Oreochromis mossambicus), Food Chem, Vol.78, No.1, 69-74.

[10] Chukwu, O. (2009). Influences of Drying Methods on Nutritional Properties of Tilapia Fish (Oreochromis niloticus), World Journal of Agricultural Sciences, Vol.5, No.2, 256-258.

[11] de Castro, F.A.F., Pinheiro Sant'Ana, H.M., Campos, F.M., Costa, N.M.B., Silva, M.T.C., Salaro, A.L. and Franceschini, S.D.C.V. (2000). Fatty Acid Composition of Three Freshwater Fishes under Different Storage and Cooking Processes, Food Chem, Vol.103, No.4,1080-1090.

[13] Hernández-Sánchez, F. and Aguilera-Morales, M.E. (2012). Nutritional Richness and Importance of the Consumption of Tilapia in the Papaloapan Region. Rev Electron Vet; Vol.13, No.6, 1-12.

[13] Steiner-Asiedu, M., Julshamn, K. and Lie, O. (1991). Effect of Local Processing Methods (Cooking, Frying and Smoking) on Three Fish Species from Ghana: Part I. Proximate Composition, Fatty Acids, Minerals, Trace Elements and Vitamins, Food Chem; Vol.40, No.3, 309-321.

[14] Abraha, B., Admassu, H., Mahmud, A., Tsighe, N., Shui, X.W. and Fang, Y. (2018). Effect of Processing Methods on Nutritional and Physico-Chemical Composition of Fish: A Review, MOJ Food Processing \& Technology, Vol.6, No.4, 376-382.

[15] Bastías, J.M., Balladares, P., Acuña, S., Quevedo, R. and Muñoz, O. (2017). Determining the Effect of Different Cooking Methods on the Nutritional Composition of Salmon (Salmo salar) and Chilean Jack Mackerel (Trachurus murphyi) Fillets, PLoS ONE, Vol. 12, No.7.

[16] Choo, P.Y., Azlan, A. and Khoo, H.E. (2018). Cooking Methods Affect Total Fatty Acid Composition and Retention of DHA and EPA in Selected Fish Fillets, ScienceAsia, Vol.44, 92-101.

[17] Moradi, Y., Bakar, J., Motalebi, A.A., Syed Muhamad, S.H. and Che Man, Y. (2011). A Review on Fish Lipid: Composition and Changes During Cooking Methods, J Aquat Food Prod Technol; Vol.20, No.4, 379390 .

* Corresponding author. Tel.: +52-281-872 9230; fax: +52-281-872 9230

E-mail address: cnolasco36@gmail.com.

Manuscript History:

Received 11 March, 2020, Revised 24 April, 2020, Accepted 29 April, 2020, Published 30 April, 2020

e-ISSN: 2289-7771 
[18] Lurie, S. and Pedreschi, R. (2014). Fundamental Aspects of Postharvest Heat Treatments, Hortic Res, 1.

[19] Jiao, Y., Tang, J., Wang, S., Koral, T. (2014). Influence of Dielectric Properties on The Heating Rate in FreeRunning Oscillator Radio Frequency Systems, J Food Eng, Vol.120, No.1, 197-203.

[20] AOAC. Official methods of analysis, 15th ed. 1990. Washington, DC: Association of Official Analytical Chemists.

[21] Garcia, P.T., Casal, J.J., Fianuchi, S., Magaldi, J.J., Rodríguez, F.J. and Nancucheo, J.A. (2008). Conjugated Linolenic Acid (CLA) and Polyunsaturated Fatty Acids in Muscle Lipids of Lamb from the Patagonian Area of Argentina, Meat Sci, Vol.79, No.3, 541-548.

[22] Huss, H.H., Ababouch, L. and Gram, L. (2004). Assessment and Management of Seafood Safety and Quality, FAO Fisheries Technical Paper 444, Food and Agricultural Organisation of the United Nations, Rome.

[23] Mustafa, F.A. and Medeiros, D.M. (1985). Proximate Composition, Mineral Content, and Fatty Acids of Catfish (Ictalurus punctatus, Rafinesque) for Different Seasons and Cooking Methods, J Food Sci, Vol.50, No.3, 585-588.

[24] Yu, T.Y., Morton, J.D., Clerens, S. and Dyer, J.M (2017). Cooking-Induced Protein Modifications in Meat, Compr Rev Food Sci Food Saf, Vol.16, No.1, 141-159.

[25] Dasgupta, M. and Kishore, N. (2017). Selective Inhibition of Aggregation/Fibrillation of Bovine Serum Albumin by Osmolytes: Mechanistic and Energetics Insights, PLoS ONE, Vol.12, No.2.

[26] De Pomerai, D.I., Smith, B., Dawe, A., North, K., Smith, T., Archer, D.B. and Candido, E.P.M. (2003). Microwave Radiation Can Alter Protein Conformation Without Bulk Heating, FEBS Lett; Vol.543, No.1-3, 93-97.

[27] Gladyshev, M.I., Sushchik, N.N., Gubanenko, G.A., Demirchieva, S.M. and Kalachova, G.S. (2006). Effect of Way of Cooking on Content of Essential Polyunsaturated Fatty Acids in Muscle Tissue of Humpback Salmon (Oncorhynchus gorbuscha), Food Chem, Vol.96, No.3, 446-451.

[28] Brühl, L. (2014). Fatty Acid Alterations in Oils and Fats During Heating and Frying, Eur J Lipid Sci Technol, 707-715. 